\title{
Comparative Ecotoxicological Assessment of Acetaminophen and Diclofenac using Freshwater African Catfish Clarias gariepinus (Burchell 1822)
}

\author{
*FOLARIN, OS; OTITOLOJU, AA; AMAEZE, NH \\ Ecotoxicology and Conservation Unit, Department of Zoology, Faculty of Science, University of Lagos, Akoka, Nigeria. \\ *Corresponding Author Email: folaheman@ gmail.com, Phone Number: +234(0)80-2838-2696
}

\begin{abstract}
The use and abuse of analgesics, commonly referred to as painkillers is on the rise globally. This study examined the acute toxicity and sub-lethal effects on liver function (ALT, AST, ALP) and anti-oxidative stress enzymes of the African Catfish, Clarias gariepinus, exposed to two analgesics, acetaminophen and diclofenac. The fingerlings (4 weeks old), were exposed to high concentrations of both analgesics to determine their acute toxicity of a $96 \mathrm{~h}$ period. The results indicated that diclofenac was approximately 500 times more toxic to the catfishes with a $96 \mathrm{~h} \mathrm{LC} \mathrm{L}_{50}$ of $2.6 \mathrm{mg} / \mathrm{L}$ compared to $1283.6 \mathrm{mg} / \mathrm{L}$ in those exposed to acetaminophen. Another batch of the catfishes was subsequently exposed to two sub-lethal concentrations $\left(1 / 10^{\text {th }} 96 \mathrm{~h} \mathrm{LC}_{50}\right.$ and $1 / 100^{\text {th }} 96 \mathrm{~h} \mathrm{LC}_{50}$ of both compounds for 28 days. The result of the sub-lethal assessment indicated that the responses were not always dose-dependent. The liver function enzyme assessments indicated a varied result with AST values slightly lower than control while ALP values were all higher in the exposed groups than the control. Only catfishes exposed to $1 / 10^{\text {th }} 96 \mathrm{~h} \mathrm{LC}_{50}$ diclofenac showed significant inhibition $(\mathrm{P}<0.05)$ of ALT enzyme activities compared to control. The activities of the anti-oxidative stress enzyme catalase were lower in those exposed to acetaminophen compared to control and this was also the case for glutathione-S- transferase (GST) activities for exposures to both concentrations of both analgesics. The findings point to the need for the inclusion of pharmaceuticals in our national effluent quality standards so as to mitigate potential harm to aquatic life.
\end{abstract}

\section{DOI: https://dx.doi.org/10.4314/jasem.v22i9.26}

Copyright: Copyright $\odot 2018$ Folarin et al. This is an open access article distributed under the Creative Commons Attribution License (CCL), which permits unrestricted use, distribution, and reproduction in any medium, provided the original work is properly cited.

Dates: Received: 28 August 2018; Revised: 10 September 2018; Accepted: 30 September 2018

Keywords: Acetaminophen, diclofenac, toxicity, catfish

Painkillers are a group of pharmaceuticals mostly used across the globe, and prominent among them are acetaminophen (generally known as paracetamol) and diclofenac (Golar, 2011; Gomaa, 2018). Diclofenac is a nonsteroidal anti-inflammatory drug generally used for treatment of inflammation while acetaminophen, on the other hand, is an antipyretic substance, which lacks anti-inflammatory effects. However, while their therapeutic effects and uses differ in many ways, these two drugs are used as an analgesic for the treatment of minor aches and musculoskeletal pains. Consumption of pharmaceutical products across the world is increasing, and this has been attributed to the rise in global population as well as the increasing need for geriatrics to depend on drugs (Arnold et al., 2014). This is likely to increase further in developing countries (Daughton, 2003) such as Nigeria where pharmaceutical production companies are flourishing due to increasing dependence on pharmaceuticals. The widespread production and use of these two pharmaceutical products (Olaitan et al., 2014) makes their eventual presence in environmental media inevitable, especially due to improper disposal of wastes by small and medium scale pharmaceutical companies (Agboola and Fawole, 2014).
Acetaminophen is a non-prescription drug widely used across the world, and it is one of the pharmaceutical products mostly detected in sewage treatment plant effluents, surface water, and drinking water (Eedris $e t$ al., 2017). These compounds have become ubiquitous in general as they find their way into the environment through point and non-point sources (Sarmah et al., 2006), including wastewater discharge from pharmaceutical production facilities, improper disposal of drugs, dumping of sewage into the water bodies, among other sources. Painkillers are the most detected of all pharmaceutical compounds investigated in water environment globally; accounting for $31 \%$ of records (Hughes, Kay and Brown, 2013) with compounds such as acetaminophen and diclofenac specifically identified as priority human pharmaceuticals for investigation (Hilton et al., 2003). In Nigeria, the presence of acetaminophen and diclofenac in groundwater and a surface water body has been confirmed by Olaitan et al. (2014). The gaps in the knowledge of the effects of exposure to such environmental pharmaceuticals have continued to generate concern among environmental scientists and regulators. For instance, toxicity of diclofenac in three Gyps vulture species has been linked to a devastating 
decline in their populations in Pakistan and India (Oaks et al., 2004). Studies have shown that a number of pharmaceutical compounds are capable of inducing oxidative stress, genotoxicity, endocrine disruption, and other biological effects in animals (Arnold et al., 2014; Backhaus, 2014).

Clarias gariepinus is one of the most abundant freshwater invertebrates in the tropics, and it is a model test species for environmental research used across West Africa in assessing toxicity of diverse compounds (Ibrahem et al., 2011). Meanwhile, studies on the toxicological effects of pharmaceuticals using the species are gradually on the rise. However, the occurrence of pharmaceuticals in water and their biological effects on aquatic organisms have not been adequately investigated (Bottoni et al., 2010). Therefore, the aim of this research is to evaluate the comparative toxicological effects of acetaminophen and diclofenac using $C$. gariepinus. The test pharmaceutical compounds were chosen for this study due to their established presence in the water while the animal model was chosen due to their ease of culture and their wide acceptance as experimental animal species.

\section{MATERIALS AND METHODS}

Preparation of stock solution of the test chemicals: The pharmaceuticals used for the experiment were technical grade purchased from Antez Scientific Stores in Lagos. A stock solution containing $1 \mathrm{mg}$ of diclofenac per $\mathrm{ml}$ of water was prepared by adding 1 gram of diclofenac to 1 litre of distilled water. Also, a stock solution of acetaminophen was prepared by dissolving 50 gram of acetaminophen in 1 litre of water to make a stock solution of $50 \mathrm{mg}$ of acetaminophen per $\mathrm{ml}$ of water.

Acute Toxicity Testing: Two hundred and seventy-five 6-week old juveniles of the African Catfish, Clarias gariepinus of the same brood were purchased from a fish farm in Akoka, Lagos and transported to the Ecotoxicology Laboratory of University of Lagos, Nigeria. The fish were kept in three plastic holding tanks $(30 \times 30 \times 60 \mathrm{~cm})$ which were three-quarters filled with de-chlorinated water. They were acclimatized to laboratory conditions for 14 days until they were acclimatized enough for bioassay. They were fed with commercial fish feed (Coppens $\left.{ }^{\circledR}\right)$ at $4 \%$ of their body weight once daily. The water in the holding tank was changed every 24 hours to prevent accumulation of toxic waste metabolite and food particles. During the 14-day period of acclimatization mortality recorded was $2.2 \%$.
After range finding tests for the two pharmaceuticals, the catfishes were randomly divided into twenty-one groups of 10 fishes per group and kept in twenty-one cubic glass tanks $(15 \times 15 \times 15 \mathrm{~cm})$ each containing $1000 \mathrm{ml}$ of de-chlorinated tap water. One of the eleven groups served as control, five groups were exposed to varying concentrations of acetaminophen in dechlorinated water $(750 \mathrm{mg} / \mathrm{L}, 1000 \mathrm{mg} / \mathrm{L}, 1250 \mathrm{mg} / \mathrm{L}$, $1500 \mathrm{mg} / \mathrm{L}$ and $1750 \mathrm{mg} / \mathrm{L}$ ); while the other five groups were exposed to varying concentrations (1 $\mathrm{mg} / \mathrm{L}, 2 \mathrm{mg} / \mathrm{L}, 3 \mathrm{mg} / \mathrm{L}, 4 \mathrm{mg} / \mathrm{L}$ and $5 \mathrm{mg} / \mathrm{L}$ ) of diclofenac in distilled water, each having two replicates. The acute toxicity testing was carried out using static renewal method over a period of 96 hours. Feeding of the fish was stopped 24 hours prior to the commencement of acute toxicity testing and throughout the $96 \mathrm{~h}$ period of exposure through static renewal bioassay. The containers were covered with mesh-sized nets to prevent the fish from jumping out. The set-up was monitored twice daily and mortality was recorded every 24 hours for 4 days. The US EPA method for acute toxicity testing was adopted for the experiment. A fish was considered dead when observed to be totally immobile with no opercula movement seen when probed with a glass rod.

Sub-lethal Toxicity Testing: After determining the 96 $\mathrm{h} \mathrm{LC} \mathrm{C}_{50}$ for the two test pharmaceutical substances, the sublethal toxicity testing was carried out. For this purpose, one hundred 14-week old adults of Clarias gariepinus of the same brood were purchased from the same fish farm in Akoka, Lagos and transported to the laboratory. The fish were kept in three plastic holding tanks $(30 \times 30 \times 60 \mathrm{~cm})$ which were half-filled with de-chlorinated water. They were also acclimatized to laboratory conditions for 14 days and were fed once daily with commercial fish pellets. The water was changed every 48 hours to prevent the accumulation of waste metabolite and food particles. During the 14-day period of acclimatization, $6 \%$ mortality was recorded. The fish were exposed to the test substances over a period of 28 days using $1 / 10^{\text {th }}$ and $1 / 100^{\text {th }}$ of the $96 \mathrm{~h}$ $\mathrm{LC}_{50}$ (expressed as $0.1 \quad \mathrm{LC}_{50}$ and $0.01 \quad \mathrm{LC}_{50}$ respectively) obtained from acute toxicity testing.

Biochemical Analysis: At the end of the sub-lethal assay the enzymatic responses of the fishes were evaluated using replicates from each exposure group including the control. Blood samples were collected using caudal vein puncture with syringes into universal bottles. The plasma was separated from the blood cells by centrifuge at $3000 \mathrm{rpm}$ for 10 minutes for liver function enzyme assessment. Liver was also collected from each of the fish, ground in a mortar, mixed with $5 \mathrm{ml}$ of deionized water and centrifuged at the rate of $3000 \mathrm{rpm}$ for 10 minutes. The supernatant 
was decanted and analysed for anti-oxidative stress enzyme activities using reduced glutathione (GSH), glutathione-S-transferase (GST), and catalase (CAT).

Catalase Activity: CAT activities were measured following the method of Claiborne (1985) and as described by Haque et al. (2003) and Ganapaty et al. (2012). The reaction mixture consisted of $0.09 \mathrm{M}$ $\mathrm{H}_{2} \mathrm{O}_{2}, 0.1 \mathrm{M}$ phosphate buffer and PMS (10\%) in a total volume of $3 \mathrm{ml}$. At $240 \mathrm{~nm}$ in every 30 seconds, change in absorbance was recorded in a double beam spectrophotometer. Catalase activity was calculated in terms of $\mathrm{nmol} \mathrm{H}_{2} \mathrm{O}_{2}$ consumed/min/mg protein.

Glutathione Activity: GSH activities were measured following the method by Jollow et al. (1974) and which was employed by Haque et al. (2003). One ml of PMS (10\%) was incubated on ice with equal volume of $4 \%$ sulphosalicylic acid (4\%). After one hour the mixture was centrifuged for $15 \mathrm{~min}\left(1200 \mathrm{rpm}, 4^{\circ} \mathrm{C}\right)$. Supernatant was filtered and the final reaction mixture (3 mL) contained filtered aliquot, 0.1 M phosphate buffer and $10 \mathrm{mM}$ DTNB. Absorbance was recorded at $412 \mathrm{~nm}$.

Glutathione S-Transferase Activity: GST activities were measured in line with the method of Watanabe et al. (1996) with slight modifications. The reaction mixture consisted of $0.5 \mathrm{ml}$ of $0.2 \mathrm{M}$ sodium phosphate buffer (NaPi, pH 6.5), $0.05 \mathrm{ml}$ of $20 \mathrm{mM}$ reduced glutathione (GSH), $0.05 \mathrm{ml}$ of $20 \mathrm{mM} \mathrm{1-}$ chloro-2,4-dinitro-benzene (CDNB), and $0.4 \mathrm{ml}$ of fish extract in a total volume of $1 \mathrm{ml}$. The change in absorbance was recorded at $340 \mathrm{~nm}$ and the enzyme activity was calculated as nmol CDNB conjugate formed $/ \mathrm{min} / \mathrm{g}$ of fish tissue.

Determination of Liver Function Enzymes Activities: The Alkaline phosphatase (ALP), Alanine Aminotransferase (ALT) and Aspartate Aminotransferase (AST) enzymes activities in the experimental fishes were measured following the methods described by Solomon and Dorcas (2014). The evaluation of ALT in the blood was carried out by adding $0.5 \mathrm{ml}$ of substrate into a test tube containing $0.5 \mathrm{ml}$ of blood, while the mixture was placed in a water bath at $37^{\circ} \mathrm{C}$ for 30 minutes. $0.5 \mathrm{ml}$ of 2,4dinitrophenylhydrazine was added to the solution and incubated for 20 minutes. Thereafter, $5 \mathrm{ml}$ of sodium hydroxide was added to mixture which turned brown and was placed in a spectrophotometer at $540 \mathrm{~nm}$ and results were obtained from the calibrated graph. ALP was determined by adding $1 \mathrm{ml}$ of $\mathrm{p}$ nitrophenylphosphatase to $1 \mathrm{ml}$ of the serum in a test tube and incubated for 30 minutes. The results were obtained from the spectrophotometer at $410 \mathrm{~nm}$ and correlated with values on the calibrated graph to give the results. AST was determined by adding sodium azide in a test tube and $0.5 \mathrm{ml}$ of the blood or serum added. It was then put in a water bath at $37^{\circ} \mathrm{C}$ for 30 minutes. After this $0.5 \mathrm{ml}$ of a 2,4 dinitrophenylhydrazine was added to the mixture, incubated for 20 minutes and $5 \mathrm{ml}$ of sodium hydroxide was added to the mixture which turned brown. It was then placed in a spectrophotometer at $540 \mathrm{~nm}$ and the results were read on the calibrated graph.

Statistical Analysis: The data obtained were analysed using SPSS software (Version 18.0) For acute studies, lethal concentration with $50 \%$ mortality $\left(\mathrm{LC}_{50}\right)$ was calculated by probit regression analysis (Finney, 1971), using IBM SPSS statistics (Version: 18). Oneway analysis of variance (ANOVA) and post-hoc were used to determine the significant difference at the $5 \%$ probability level.

\section{RESULTS AND DISCUSSION}

The results of the acute toxicity assay indicated that mortality was dose dependent and increased between $24 \mathrm{~h}$ and $96 \mathrm{~h}$ of exposure to acetaminophen (Table 1). This was also the case for fish exposed to diclofenac while $50 \%$ mortality was recorded in the groups exposed to $4 \mathrm{mg} / \mathrm{L}$ (Table 2). The calculated $96 \mathrm{~h} \mathrm{LC}_{50}$ of acetaminophen and diclofenac for the exposed catfishes were $1283.6 \mathrm{mg} / \mathrm{L}$ and $2.6 \mathrm{mg} / \mathrm{L}$ respectively implying that the diclofenac is approximately 500 times more toxic than acetaminophen. The findings from the acute toxicity assessment are clearly indicative that diclofenac is highly toxic to $C$. gariepinus and much more toxic than acetaminophen. However, The $96 \mathrm{~h} \mathrm{LC} 50$ of diclofenac for $C$. gariepinus recorded in this study was lower than 25.12 $\mathrm{mg} / \mathrm{l}$ being the $96 \mathrm{~h} \mathrm{LC} \mathrm{LC}_{50}$ of diclofenac for $C$. gariepinus recorded by Ajima et al. (2015).

Table 1: Acute toxicity response of $C$. gariepinus to acetaminophen after $96 \mathrm{~h}$

\begin{tabular}{lccc}
\hline Concentration $(\mathbf{m g} / \mathbf{L})$ & Total Exposed & Response & Percentage Mortality (\%) \\
\hline 0 & 20 & 1 & 5 \\
750 & 20 & 2 & 10 \\
1000 & 20 & 5 & 25 \\
1250 & 20 & 9 & 45 \\
1500 & 20 & 12 & 60 \\
1750 & 20 & 17 & 85 \\
\hline
\end{tabular}


Table 2: Acute toxicity response of C. gariepinus to diclofenac after $96 \mathrm{~h}$

\begin{tabular}{lccc}
\hline Concentration (mg/L) & Total Exposed & Response & Percentage Mortality (\%) \\
\hline 0 & 20 & 1 & 5 \\
1 & 20 & 7 & 35 \\
2 & 20 & 10 & 50 \\
3 & 20 & 11 & 55 \\
4 & 20 & 10 & 50 \\
5 & 20 & 12 & 60 \\
\hline
\end{tabular}

Also, Praskova et al. (2011) reported an $\mathrm{LC}_{50}$ of 6.11 $\mathrm{mg} / \mathrm{L}$ diclofenac in zebra fish embryos over a period of $144 \mathrm{~h}$.

Liver Function Enzyme Activities: At the end of the 28-day sub-lethal assay, the results obtained showed that AST activities in the catfishes exposed to acetaminophen and diclofenac were lower when compared to the control group. AST activities in fish exposed to $0.1 \mathrm{LC}_{50}$ of diclofenac were significantly lower $(\mathrm{P}<0.05)$ than the control (Figure 1). ALT activities in the fish exposed to $0.1 \mathrm{LC}_{50}$ of acetaminophen and diclofenac decreased significantly $(\mathrm{P}<0.05)$ at the end of the exposure period compared to the control. The reverse was the case in those exposed to $0.01 \mathrm{LC}_{50}$ of both pharmaceuticals on the other hand, had ALT activities significantly higher than the control (Figure 2). The ALP levels in the fish exposed to the two test substances increased at the end of the experiment in a dose dependent manner. The level of ALP in fish exposed to $0.1 \mathrm{LC}_{50}$ diclofenac increased significantly compared to the levels in the control fish $(\mathrm{p}<0.05)$ (Figure 3). In this study, exposure to acetaminophen and diclofenac at sublethal concentrations was found to induce considerable changes in the activities of liver function enzymes. Specifically, the levels of AST in the test organisms exposed to the two pharmaceuticals were lower when compared to the control group. Also, the ALP levels in the fish exposed to the test substances increased at the end of the experiment, and this could be an indication of phosphate ingestion by the exposed fish (Edori et al., 2013)

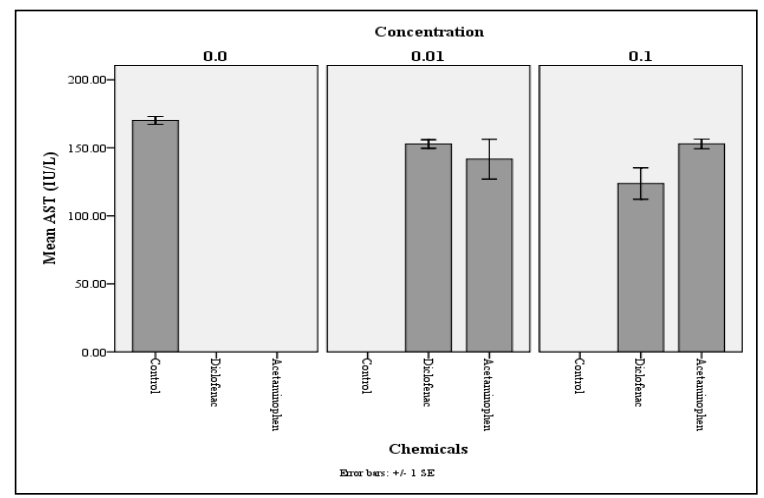

Fig 1: Aspartate Aminotransferase activity level in C. gariepinus exposed to acetaminophen and diclofenac for 28 days

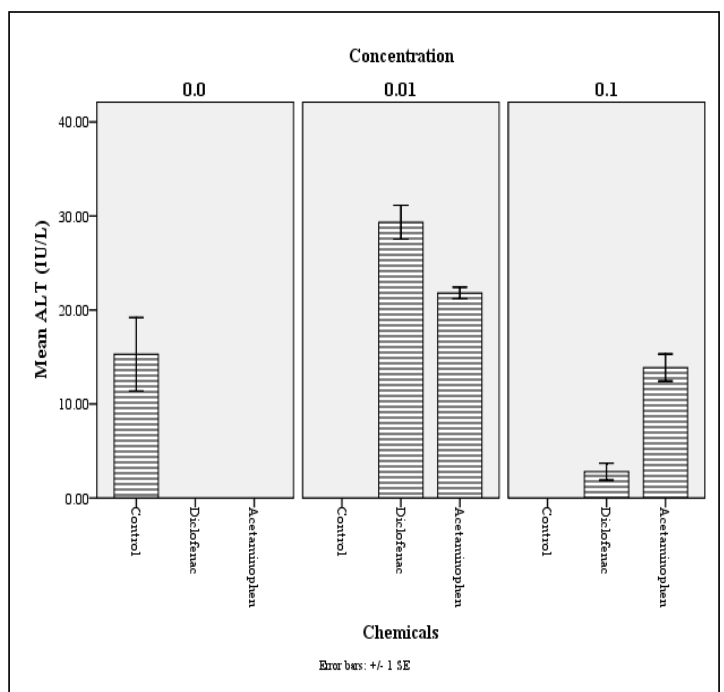

Fig 2: Alanine Aminotransferase activity level in C. gariepinus exposed to acetaminophen and diclofenac for 28 days

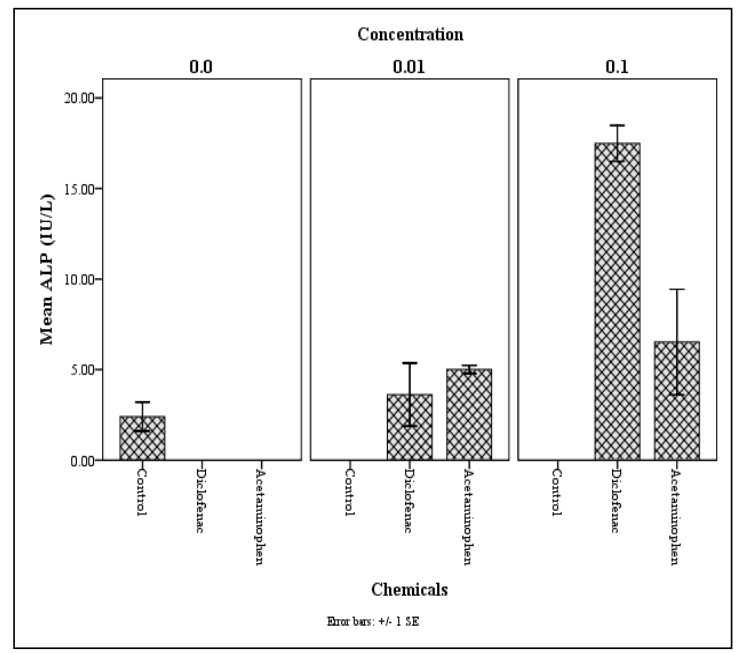

Fig 3: Alkaline Phosphatase activity level in C. gariepinus exposed to acetaminophen and diclofenac for 28 days

. The elevated level of ALP implies overproduction of phosphate-bound esters (Gabriel et al., 2009 as cited by Edori et al., 2013). The activities of ALT in the catfishes exposed to $0.1 \mathrm{LC}_{50}$ of acetaminophen and diclofenac decreased at the end of the experiment compared to the control. The results negate the findings of Ajima et al. (2015) who reported significantly higher levels of ALT and AST in $C$. gariepinus exposed to diclofenac relative to the 
control. However, the catfishes in the report of Ajima et al. (2015) were exposed to higher concentrations of diclofenac over longer duration. Nevertheless, lowered activity of AST and ALT in C. gariepinus exposed to toxicant is indicative of inactive transamination and oxidative deamination as opined by Akani and Gabriel (2016).

Anti-oxidative Stress Enzyme Activities: Oxidative stress is a situation when an organism's internal resistance of anti-oxidative stress enzymes has yielded to the onslaught of reactive oxygen species. The CAT activities in the fish exposed to $0.1 \mathrm{LC}_{50}$ diclofenac was significantly lower than the control while for acetaminophen, CAT activities in fish exposed to 0.01 $\mathrm{LC}_{50}$ concentration was significantly lower than the control as well (Figure 4). The reduced glutathione (GSH) level in the catfishes exposed to $0.01 \mathrm{LC}_{50}$ diclofenac was lower than the control while there was an elevated level of GSH in the group exposed to 0.1 $\mathrm{LC}_{50}$ of diclofenac (Figure 5). However, there was no significant difference in the activities of GSH between the control group and exposed fish $(<0.05)$. With respect to GST activities, it was observed that fish exposed to $0.01 \mathrm{LC}_{50}$ concentration of diclofenac had significantly lower levels compared to the control but those exposed to the higher concentration (i.e, 0.1 $\mathrm{LC}_{50}$ ) did not have GST activity significantly different from the control. There was, however, no significant difference for both concentrations in relation to the control for the fish exposed to acetaminophen (Figure 6). Oxidative stress has been reported in non-target organisms in circumstances associated with pollution due to the rising presence of pharmaceuticals in the environment. Specifically, significant response of oxidative stress was established in Oncorhynchus mykiss exposed to acetaminophen (Ramos et al., 2014).

Glutathione level in the catfish exposed to $0.01 \mathrm{LC}_{50}$ diclofenac was lower than the control while there was an elevated level in the group exposed to $0.1 \mathrm{LC}_{50}$ diclofenac. This implies that $0.01 \mathrm{LC}_{50}$ diclofenac did not trigger oxidative stress while $0.1 \mathrm{LC}_{50}$ diclofenac caused oxidative stress in the exposed catfish. However, the GSH levels in both concentrations of exposure were not significantly different. The analgesic, ibuprofen in another study by Bartoskova $e t$ al. (2013) was found not to affect the activity of glutathione reductase and catalase in zebrafish but caused an elevated level of glutathione peroxidase. Continuous oxidative damage could incapacitate the cells and eventually degrade completely the selfdefence mechanisms of the cells (Birben et al., 2012). At this point, the antioxidant enzymes activity becomes lower than normal.

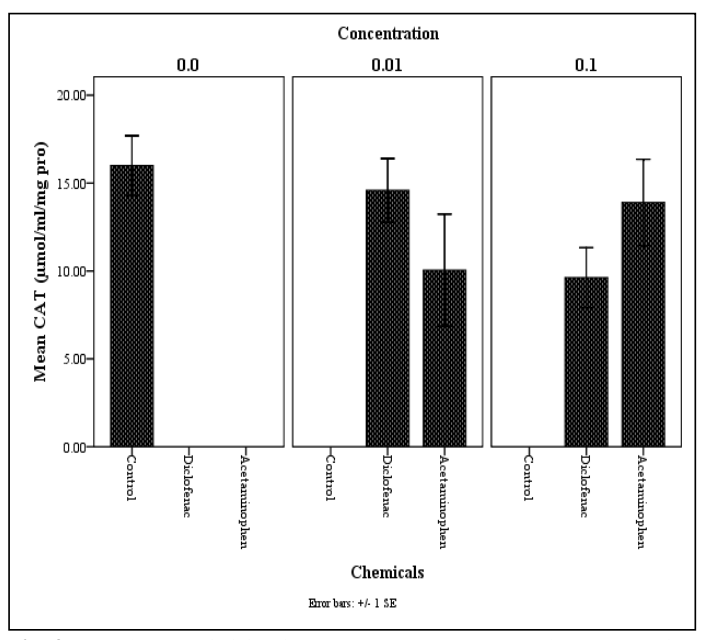

Fig 4: Catalase activities in C. gariepinus exposed to acetaminophen and diclofenac for 28 days

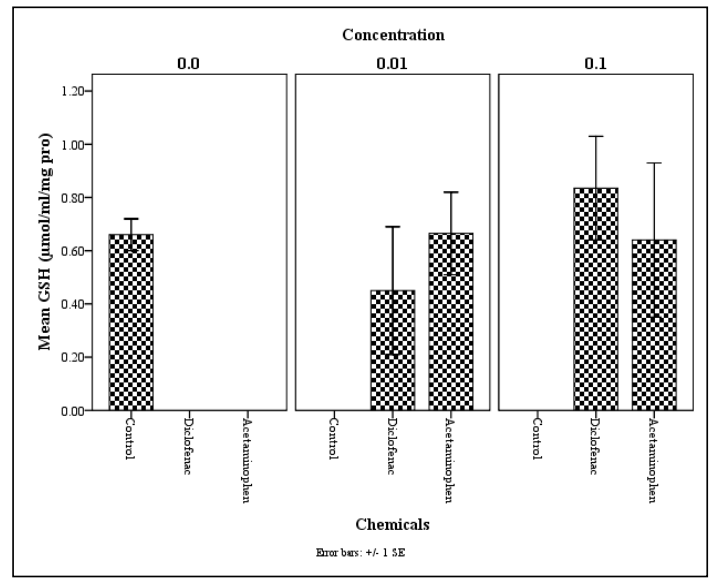

Fig 5: Reduced Gluthathione level in C. gariepinus exposed to acetaminophen and diclofenac for 28 days

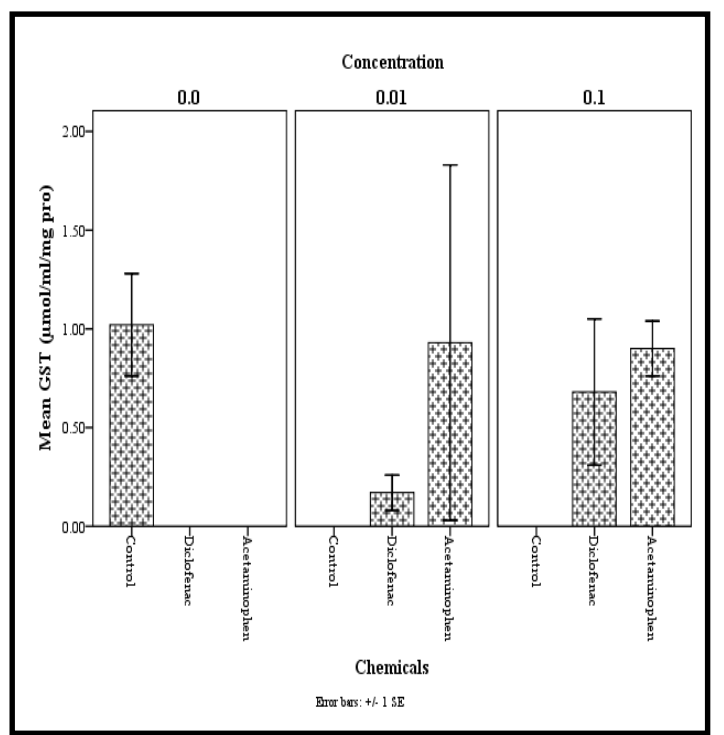

Fig 6: Gluthathione-S-Transferase (GST) activities in C. gariepinus exposed to acetaminophen and diclofenac for 28 days 
Decreased level of antioxidant activities in diseased individuals have also been reported by Maggio et al., (2003) and Patil et al. (2010). Also notable from the findings in this study is the inhibition of CAT activities in the catfishes exposed to both concentrations of diclofenac. Also, reduction in catalase activity after prolonged period of rats' exposure to fipronil has been reported by Tukhtaev (2013).

Acetaminophen and diclofenac are two major pharmaceuticals continuously released into the aquatic environment from industries and homes. Although their environmental concentrations in water column and sediments are extremely low as reported in many literatures, their pseudo-persistence in the environment predisposes aquatic organisms to possible adverse biological effects over a long period of exposure.

Conclusion: This study shows that acetaminophen and diclofenac, which have been established to be present in the aquatic environment, are capable of inducing biological effects in Clarias gariepinus. In addition, diclofenac had shown to be more toxic than acetaminophen and a trace concentration of diclofenac in aquatic environment poses threat to fish and other non-target aquatic organisms. The findings from this study raise concerns about the ecological risks associated with indiscriminate discharge of pharmaceutical effluents, which are either untreated or improperly treated before discharge. This calls for review of the national effluent guidelines to include threshold limits for regulation of pharmaceuticals as emerging pollutants in industrial wastewaters.

\section{REFERENCES}

Agboola, OA; Fawole, OO (2014). Chronic Toxicity of Pharmaceutical Effluent to Clarias gariepinus (Burchell, 1822). CJPL 1(2):27-42.

Ajima, MN; Ogo, OA; Audu, BS; Ugwoegbu, KC (2015). Chronic diclofenac (DCF) exposure alters both enzymatic and

haematological profile of African catfish, Clarias gariepinus. Drug Chem Toxicol. 38(4):38390.

Akani, N; Gabriel, UU (2016). Enzymatic responses of Clarias gariepinus (Burchell, 1822) exposed to sublethal concentrations of an oilfield wastewater. Journal of Applied Biology \& Biotechnology 4(05):026-032.

Arnold, KE; Brown, AR; Ankley, GT; Sumpter, JP (2014). Medicating the environment: assessing risks of pharmaceuticals to wildlife and ecosystems. Philos. Trans. Royal Soc. B. 19, 369 (1656). pii: 20130569. doi: 10.1098/rstb.2013.0569.
Backhaus, T (2014). Medicines, shaken and stirred: a critical review on the ecotoxicology of pharmaceutical mixtures. Philos. Trans. Royal Soc. B. 369. 10.1098/rstb.2013.0585.

Bartoskova, M; Dobsikova, R; Stancova, V; Faggio, C (2018). Evaluation of ibuprofen toxicity for zebrafish (Danio rerio) targeting on selected biomarkers of oxidative stress. Neuro Endocrinol Lett. 34(2):102108.

Birben, E; Sahiner, UM; Sackesen, C; Erzurum, S; Kalayci, O (2012). Oxidative Stress and Antioxidant Defense. World Allergy Organ J. 5(1): 9-19.

Bottoni, P; Caroli, S; Caracciolo, AB (2010). Pharmaceuticals as priority water contaminants. Toxicol Environ Chem. 92(3): 549-565.

Canayakin, D; Bayir, Y; Baygutalp, NK; Karaoglan, ES; Atmaca, HT; Ozgeris, FBK; Keles, MS; Halici, Z (2016). Paracetamol-induced nephrotoxicity and oxidative stress in rats: the protective role of Nigella sativa. Pharm Biol. 54(10): 2082-2091.

Claiborne, A (1985). Catalase activity. In: Greenwald, R.A., Ed., CRC Handbook of Methods for Oxygen Radical Research, CRC Press, Boca Raton, 283-284.

Daughton, CG (2003). Green Pharmacy: MiniMonograph: Cradle-to- cradle stewardship of drugs for minimizing their environmental disposition while promoting human health. I: Rationale for and avenues toward a Green Pharmacy. Environ Health Perspect. 111 (5): 757-774.

Edori, OS; Dibofori-Orji, AN; Edori, ES (2013). Biochemical changes in plasma and liver of Clarias gariepinus exposed to paraquat. J Pharm Biol Sci. 8(2): 35-39.

Edrees, WHA; Abdullah, QYM; Al-Kaf, AG; Naji, KM (2017). A review on comparative study between the physiochemical and biological processes for paracetamol degradation. Univers. J. Pharm. Sci. Res. 2(2): 18-27

Ezenwaji, NE; Yenagoa, B; Nwaigwe, C (2013). Changes in liver and plasma enzymes of Clarias gariepinus exposed to sublethal concentration of diesel. Afr. J. Biotechnol. 12(4): 414-418.

Farombi, EO; Adelowo, OA; Ajimoko, YR (2007). Biomarkers of oxidative stress and heavy metal levels as indicators of environmental pollution in African cat fish (Clarias gariepinus) from Nigeria Ogun River. Int J Environ Res Public Health. 4(2): 158-165.

Finney, DJ (1971). Probit analysis: A statistical treatment 
of the sigmoid response carve. Cambridge: Cambridge University Press. 333 pp.

Ganapaty, S; Chandrashekhar; VM; Lakshmi, NM; Raghavendra, HL (2012). Antioxidant Activity of Natural Products against Aluminium Fluoride Induced Oxidative Stress. Sci. Technol. Arts Res. J. 1(1): $26-37$.

Golar, SK (2011). Use and understanding of analgesics (painkillers) by Aston university students. Bioscience Horizons: The International Journal of Student Research 4(1): 71-78.

Gomaa, S (2018). Adverse effects induced by diclofenac, ibuprofen, and paracetamol toxicity on immunological and biochemical parameters in Swiss albino mice. $J$ Basic Appl Zool. 79:5 https://doi.org/10.1186/s41936-018-0025-7

Haque, R; Bin-Hafeez, B; Parvez, S; Pandey, S; Sayeed, I, Ali, M; Raisuddin, S (2003). Aqueous extract of walnut (Juglans regia L.) protects mice against cyclophosphamide induced biochemical toxicity. Hum Exp Toxicol. 22(9):473-480.

Ibrahem, MD; Shaheed, IB; Abo El Yazeed, H; Korani, $\mathrm{H}$ (2011). Assessment of the susceptibility of polyculture reared African catfish and Nile tilapia to Edwardsiella tarda. J Am Sci. 7 (2011), pp. 779-786

Jollow, DJ; Michell, JR; Zampaglionic, N; Gillete, JR (1974) Bromoibenzene-induced Liver necrosis: Protective role of glutathione and evidence for 3,4Bromobenzene oxide as hepatotoxic metabolite. Pharmacology 11: 151-169.

King, EJ and Armstrong, AR (1934). A convenient method for determining serum and bile phosphatase activity. CMAJ. 31: 376-381.

Maggio, D; Barabani, M; Pierandrei, M; Polidori, MC; Catani, M; Mecocci, P; Senin, U; Pacifici, R; Cherubini, A (2003). Marked decrease in plasma antioxidants in aged osteoporotic women: results of a cross-sectional study. J. Clin. Endocrinol. Metab. 88(4):1523-1527.

Martínez-Álvarez RM; Morales AE; Sanz, A (2005). Antioxidant defenses in fish: biotic and abiotic factors. Rev. Fish Biol. Fish. 15(1-2):75-88.

Oaks, JD; Gilbert, M; Virani, MZ; Watson, RT; Meteyer, CU; Rideout, BA; Shivaprasad, HL; Ahmed, S; Chaudhry, MJI; Arshad, M; Mahmood, S; Ali, A; Khan, AA (2004). Diclofenac residues as the cause of vulture population decline in Pakistan. Nature 427: 630-633
Olaitan, OJ; Anyakora, C; Bamiro, T; Tella, AT (2014). Determination of pharmaceutical compounds in surface and underground water by solid phase extraction-liquid chromatography. J. Environ. Chem. Ecotoxicol. 6(3): 20-26.

Patil, S; Reddy, GR; Krishna, AP; Damodara GKM (2010. Evaluation of antioxidant deficit and lipid profile in Type - 2 Diabetes Mellitus patients. Res $J$ Pharm Biol Chem Sci. 1(4): 467-474.

Praskova, E; Plhalova, L; Chromcova, L; Stepanova, S; Bedanova, I; Blahova, J; Hostovsky, M; Skoric, M; Maršálek, P; Voslarova, E; Svobodova, Z (2015). Effects of subchronic exposure of diclofenac on growth, histopathological changes, and oxidative stress in zebrafish (Danio rerio). ScientificWorldJournal http://dx.doi.org/10.1155/2014/645737

Ramos, AS; Correia, AT; Antunes, SC; Concalves, F; Nunes, B (2014). Effect of acetaminophen exposure in Oncorhynchus mykiss gills and liver: Detoxification mechanisms, oxidative defence system and peroxidative damage. Environ Toxicol Pharmacol. 37(3): 1221-1228.

Sarmah, AK; Meyer, MT; Boxall, AB (2006). A global perspective on the use, sales, exposure pathways, occurrence, fate and effects of veterinary antibiotics (VAs) in the environment. Chemosphere 65: 725-759.

Solomon, RJ; Dorcas, IK (2014). Calculation of liver function test in Clarias gariepinus collected from three commercial fish ponds. J Nat Sci. 12(10): 107 123.

Stara, A; Kouba, A; Velisek, J (2014). Effect of chronic exposure to prometryne on oxidative stress and antioxidant response in red swamp crayfish (Procambarus clarkii). Biomed Res Int.. doi: $10.1155 / 2014 / 680131$

Tukhtaev, KR; Tulemetov, SK; Zokirova, NB; Tukhtaev, NK; Tillabaev, MR; Amirullaev, OK; Yarieva, OO; Otajonova, AN (2013). Prolonged exposure of low doses of fipronil causes oxidative stress in pregnant rats and their offspring. Internet $J$. Toxicol. 10(1): 1-8.

Watanabe, R; Kinoshita, T; Masaki, R; Yamamoto, A; Takeda, J; Inoue, N (1996). PIG-A and PIG-H, which participate in glycosylphosphatidylinositol anchor biosynthesis, form a protein complex in the endoplasmic reticulum. J Biol Chem. 271: 2686826875. 